\title{
Something to Do: The Ideology of Influence and the Context of Contemporary Feminism
}

Feminist critics have turned eagerly to both Eliot and Woolf as magnificent contradictions of all those prohibitions against women in the sanctum of art- "Women can't paint, women can't write," says Charles Tansley to Lily Briscoe (TL 75) - yet they are often disturbed to find in the novels an insistence on the suffering and silence of women. The authors appear to declare the rights of women to a place in history, yet also to depict that place as an obscure, retiring one. What presuppositions about the nature of womanhood and sexual difference governed their fiction as well as their writings on womanhood, on women's education and vocation, and what gender ideology guided their own rather reserved association with women reformers? The answers I offer to these questions suggest the need for a more fully elaborated ideological history of the women's movement. Instead, I can only trace here some especially intriguing intersections of Eliot's and Woolf's ideology of influence with that of some contemporaries.

\section{Eliot and Woolf on the Nature of Womanhood}

Like most nineteenth-century partisans of women's interests and like many feminist factions today, these English women of letters waffle in the debate about nature versus nurture. On the one hand, their narratives can be shown to undermine the illusion that historically conditioned differences in gender are natural and inevitable. On the other hand, they can be caught again and again conflating biological sex with cultural gender, smuggling into their texts a sentimental belief in the inherent and timeless (if not literally innate) femininity- 
and superiority-of women. Why this fondness for what we would grandly call "difference" persists among some of those who have speculated most profoundly about sexual roles is an intriguing question, since a mystified "womanhood" has been the shibboleth of oppression. But it is certainly true that Eliot and Woolf both leaned toward this mystified difference.

Eliot and Woolf are in good company in their desire to preserve some aspect of the "nature" of womanhood from the effects of historical conditioning; the many feminists who have resisted seeing difference as an entirely historical construct have shared at least one compelling reason for doing so (besides the obvious-itself historically conditioned-basis of biological sex). If culture were entirely responsible for a perceived femininity, what would become of the virtue of not resembling the patriarch in the event that all oppressive conditions were rectified? If everyone were "like men," aggressive, calculating, power-hungry (and in many Victorians' view, uniquely sex-hungry), etc., etc., history would be a merciless chronicle. Hence the temptation to invoke what I call the ideology of influence: a belief that women have a direct line to the sources of human emotion, and that their selfsacrificing love (or in a current version, their interest in relationships rather than power or justice) "mitigates the harshness of all fatalities," in Eliot's words. This ideology of influence, which came into full flower after the 1830 s andustrialization exaggerated the division between men in the workplace and women in the home (or in underpaid, segregated labor [Hartmann 207-13]), sought to redefine womanhood as a mission rather than a mere handicap. Thus, even if one protested the sacrifice of "many Dorotheas," one could without sense of treachery exalt the influence of the women sacrificed (M 612). The alternative might be no alternative, or alterity, at all. The norm of masculine egotism, of a struggle for domination in the political and economic realm, might govern all human existence. The logic of polarities thus generates a mystified historical other, even as those who invoke it try to reach beyond polarities: women's influence is toward reconciliation, what Eliot envisioned as a harmony of the sexes, and Woolf as an androgyny beyond sexual self-consciousness.

Eliot's writings exhibit all the ambivalence of her contemporaries when they criticize the historical position of women yet defend the special qualities of influence. Eliot's earlier writings, preceding the more widespread agitation for women's causes in the 186os, show more inclination to hasten the progress toward equality of the sexes that she assumes is inexorably underway. At times claiming that women exert "a conservative influence" almost by nature ("The Natu- 
ral History of German Life" 275), she nevertheless succinctly states the case for a cultural view of the "sex/gender system" (Rubin 168) when she acknowledges the radical innovations of such women as Margaret Fuller and Mary Wollstonecraft. An oppressive society has created feminine inferiority:

On one side we hear that woman's position can never be improved until women themselves are better; and, on the other, that women can never become better until their position is improved. . . . But we constantly hear the same difficulty stated about the human race in general. There is a perpetual action and reaction between individuals and institutions; we must try and mend both by little and little. . . . Unfortunately, many overzealous champions of women assert their actual equality with men-nay, even their moral superiority to men. ... But we want freedom and culture for woman, because subjection and ignorance have debased her, and with her, Man. ("Margaret Fuller and Mary Wollstonecraft" 205)

It may seem promising here that Eliot will not overzealously claim women's moral superiority, and that she calls for a wider field of endeavor for women because they have been defined by oppressive customs; whatever the nature, nurture has much to answer for (compare Lewes, "Lady Novelists," 7).

Eliot has little love for idolized women as they are. Thus she praises Wollstonecraft and Fuller but objects to that domestic monstrosity, the "doll-Madonna in her shrine"; warbling in her gilded cage like Rosamond Vincy, she is often a harpy who debases a "man of genius." Indeed Eliot can be almost as hostile as Woolf toward the Victorian domestic idol, the Angel in the House, though Eliot follows tradition in commiserating with the Angel's husband rather than her daughters. Hints of direct conflict with the feminine ideal, however, make Eliot uneasy. She cannot kill the Angel in the House as Woolf advises the woman writer to do; she merely condemns her to a hell of falsity and selfishness.

It seems that Eliot cannot sustain her historical analysis of gender and the subjection of women. When women verge on Romantic egotism, she tends to revert to arguments of innate femininity. She praises

\footnotetext{
1"Margaret Fuller and Mary Wollstonecraft" 204. Without the added story of "Miss Brooke," Middlemarch might appear to retell the old misogynist story of genius destroyed by woman. But Dorothea in contrast to Rosamond could really have helped a man if he were indeed a genius. The artificial product of Mrs. Lemon's school and the bourgeois drawing room, not a concept of female nature, is being criticized.
} 
the "brave" and "strong" Margaret Fuller and Mary Wollstonecraft because they are not the demon opposites of household angels: they still listen to "the beating of a loving woman's heart, which teaches them not to undervalue the smallest offices of domestic care or kindliness" (201; compare Woolf on Wollstonecraft, "Four Figures," CE 3: 193-99). Here we suspect a sentimental association of women's innate tendencies ("heart") with domestic self-sacrifice, only in a more active and unselfish mode than the doll-Madonna's. Eliot's ideal woman's role might be called the domestic public servant: a woman ministering to human need in the marginal realm of charity or social causes, whereby, for example, the hospital can be seen as the household sickroom "multiplied." ${ }^{2}$ Her own role as novelist likewise bridges the private moment of the reader at home and the public domain of epochs in the national life, as well as the massive "public" or audience conjured up by her novels. (In N. N. Feltes's Althusserian interpretation, Eliot "interpellated a special audience," as she won her bid for "professional status," in part by "displaying publicly" her unwomanly individual rights [49].) Thus the apparent egotism of the public woman, from Wollstonecraft to herself, may be exonerated if the woman's "heart" still conceives its vocation in domestic terms (Homans 153).

An appeal to the womanly "heart" was almost universal in Victorian writings on the woman question, but it was sometimes accompanied by a less essentialist conception of women's role, especially among the women and men who like Eliot were familiar with the ideas of Spencer, Comte, John Stuart Mill, and others associated with the Social Science Congress (Myers, Teaching of Eliot, 5-9). Eliot's interest in developmental or evolutionary social science helped her to call attention to cultural variations, as when she notes the achievements

\footnotetext{
${ }^{2}$ Austen seems to recognize early on the parallel vocations of nurse and woman novelist when Mrs. Smith praises Nurse Rooke in Persuasion: "Hers is a line for seeing human nature. . . . Call it gossip if you will; but . . . nurse Rooke . . . is sure to have something to relate that is entertaining and profitable, something that makes one know one's species better." Anne Elliot and Mrs. Smith agree that "a sick chamber may often furnish the worth of volumes" (168; Spacks, Gossip, 57). Anna Jameson in 1855 and 1856 delivered lectures urging ladies to take up public charity "to perform socially the household-work"; "a woman begins by being the nurse, the teacher, the cherisher of her home, through her greater tenderness and purer moral sentiments; then she uses these qualities and sympathies on a larger scale, to cherish and purify society." Advancing civilization "multiplie[s] and diffuse[s]" the complementary domestic relations of man and woman (Sisters of Charity 5-6; Bauer and Ritt 81-82). Though Eliot could not have attended Jameson's lectures (she was not in England in February 1855, when the first was delivered, and she was not welcome in polite female circles), she would probably have read the published versions, in which her acquaintance expresses views quite similar to her own on women's potential influence.
} 
of cultivated French women during the Enlightenment ("Woman in France: Madame de Sablé" 54, 58). Yet this same empiricist bias betrays her when she too readily attributes biological origins to perceived characteristics. Eliot would undoubtedly have concurred with John Stuart Mill when he noted in The Subjection of Women that "unnatural generally means only uncustomary" with regard to sexual roles; yet we see in her works an unacknowledged clinging to what Mill calls the "moralities . . . and . . . sentimentalities" that tell women "it is their [duty and] nature, to live for others" $(22,27)$.

For Eliot, the idea of a biological burden is readily transposed into a moral mission. As she wrote to John Morley in 1867 apropos of the debate over Mill's amendment for the franchise for women,

I would certainly not oppose any plan ... to establish as far as possible an equivalence of advantages for the two sexes, as to education and the possibilities of free development. . . . I never meant to urge the 'intention of Nature' argument, which is to me a pitiable fallacy. I mean that as a fact of mere zoological evolution, woman seems to me to have the worse share in existence. But for that very reason . . . in the moral evolution we have "an art which does mend nature" - an art which "itself is nature." It is the function of love in the largest sense, to mitigate the harshness of all fatalities.

The "zoological" difference between men and women is a boon in that it teaches humanity to recognize its own progress toward "a more clearly discerned distinctness of function (allowing always for exceptional cases [such as herself?]. . .)," while the inequalities of this difference are "a basis for a sublimer resignation in woman and a more regenerating tenderness in man. ${ }^{\prime 3}$ Nature, or the womanly art of love which is nature, seems to be the only certainty in a tenuous struggle toward "equivalence of good for woman and for man." ${ }^{\prime 4}$ Thus the "pitiable fallacy" of biological destiny creeps back in in spite, or because,

\footnotetext{
${ }^{3}$ The belief in progress as an increasing organic differentiation was a favorite with such writers as Spencer (see "Progress: Its Law and Cause" [1857], 13: 14-17); Eliot here calls it "the one conviction on the matter [of sexual roles] which I hold with some tenacity." See Levine, "Eliot's Hypothesis," 8. I quote the letter to John Morley from Haight, Selections from George Eliot's Letters, 331-32, because the complete edition omits the phrase "-an art which 'itself is nature,' " and because it has: "I meant to urge the 'intention of Nature' argument" (GE Letters 4: 364-65).

${ }^{4}$ Eliot, borrowing the Bard's authority, contributes to the tradition of horticultural imagery that I later discuss, when she alludes to Polixenes' debate with Perdita over the propriety of hybrids (The Winter's Tale IV.iv.78-135). By affirming that cultivation also is nature, Polixenes alerts us to the inverse idea that no nature is not also culture.
} 
of an attempt to represent women as active partners in human progress. Without innate difference, and hence without the need for "resignation," Eliot implies, there would be no regeneration for men, nothing but harsh fatality.

Eliot wrote similarly equivocal pronouncements to her friend Emily Davies, the pioneer of women's higher education, during the height of the struggle to found Girton, the first women's college affiliated with "Oxbridge." The letter begins with a self-censorship that is also weighty advice to the woman who will be addressing the public:

Pray consider the pen drawn through all the words and only retain certain points ... as a background to all you may . . . say to your special public.

1. The physical and physiological differences between women and men. . . . These may be said to lie on the surface. . . . But . . . the differences are deep roots of psychological development. . . .

2. The spiritual wealth acquired for mankind by the difference of function founded on the other, primary difference; and the preparation that lies in woman's peculiar constitution for a special moral influence. In the face of all wrongs, mistakes, and failures, history has demonstrated that gain. And there lies just that kernel of truth in the vulgar alarm of men lest women should be 'unsexed' [by education]. We can no more afford to part with that exquisite type of gentleness, tenderness, possible maternity suffusing a woman's being with affectionateness, . . . than we can afford to part with the human love, the mutual subjection of soul between a man and a woman-which is also a growth and revelation beginning before all history.

... Complete union and sympathy can only come by women having . . . the same store of acquired truth or beliefs as men have, so that their grounds of judgment may be as far as possible the same. (GE Letters 4: 467-68)

Here Eliot envisions historical change-increasing education for women-as a means of restoring a kind of Platonic, pre- or ahistorical union between man and woman. At the same time she cannot resist the vulgar anxiety to preserve a feminine ideal that depends on separate "grounds of judgment." Like Mary Wollstonecraft, in other words, Eliot would have males and females educated together in order to promote mutual understanding, but unlike Wollstonecraft $(86,107-$ 9) she distrusts a monolithic, masculine norm for all human beings. What would we do without difference? Like the Victorian opponents 
of equal education whom Ray Strachey describes, Eliot wishes to preserve "that special and peculiar bloom which they regarded as woman's greatest charm, . . . that valuable, intangible 'superiority' of women" (Strachey 143). Eliot's sibilant words, "gentleness, tenderness, possible maternity suffusing . . . with affectionateness," seem nervous approximations of an ideal very much like Ruskin's in "Of Queen's Gardens."

But Eliot is not quite the advocate of arrested female development that this likeness to Ruskin and the guardians of bloom suggests. It is less the intention of nature that concerns Eliot than the intention of women: they must retain their selflessness to mend the "hard nonmoral outward conditions" that men more directly contend with (GE Letters 4: 365). In The Mill on the Floss, at least in the early books, Eliot treats the notion of womanly "bloom" with bitter sarcasm, disparaging the system that prevents Maggie from learning Latin. But the novel implies that if a masculine education cultivates the sword-swinging and cruel "justice" of her brother Tom, Maggie is better off learning through her suffering. ${ }^{5}$ Most readers undoubtedly side with Maggie, though we may resist the novel's pressure to concur in her sacrifice.

This sympathy for Maggie is not only a rhetorical effect, I believe, but also an effect of prejudice in favor of the feminine: many of us still feel the attraction of the myth of the "intangible 'superiority' of women." Less dubiously, I think we need not be ashamed of wishing to see "gentleness, tenderness, ... . affectionateness" incarnated in powerful forms, preferably female and male, without the prescription that those born female must be more selfless than those born male. Bloom and influence are deeply sinister ideals as the strategies of the marginalized, but it would be misguided therefore to value only selfinterested plain-dealing on the masculine model. If most feminists now abhor the silent, disembodied lady of the Victorian imagination, they do not therefore repudiate all things "feminine" as though women must advance by becoming "manlike." Eliot's and Woolf's defense of feminine or selfless heroism seems an attempt to escape the dichotomy between the man's ability to exploit and the woman's ability to remain chaste. If Maggie's sacrifice to the flood and family history seems more disturbing than Miss La Trobe's immolation, at the end of Between the Acts, in a flood of words for the sake of a new

${ }^{5}$ Tom has a promising moment early in his education-a process of plowing and harrowing - when he takes the feminine point of view of the field being "plowed and harrowed." "Tom became more like a girl than he had ever been in his life," and he even resembles the benighted " 'masses' " (MF 124-25; Jacobus, Reading Woman, 6974). 
history of the human family, both can be seen as offering an escape from self that might also be an end to essentialized gender.

Woolf persists in the Victorian hopes for women's education and the alteration of the nurture that has suppressed women, but she also shares the Victorians' nostalgia for natural difference. In A Room of One's Own she eulogizes "that extremely complex force of femininity" that has infused the rooms of civilization for ages, and she suggests that it be preserved (though she also speculates that womanhood itself may become obsolete): "For if two sexes are quite inadequate, considering the vastness and variety of the world, how should we manage with one only? Ought not education to bring out and fortify the differences rather than the similarities?" (RO 91). Such differences might even be biologically based: "The nerves that feed the brain would seem to differ in men and women" (81). In tracing a history of women's cultural advancement, however, she seems to reject the oppressive virtues of woman's mission: "Do not dream of influencing other people," she advises her audience of university women (115). In Three Guineas, she nevertheless revives the Ruskinian belief in a separate sphere or mission: she urges educated men's daughters to shun the avenues to power newly opening to women and instead to consolidate their outsiders' influence. Yet in recommending the virtues of "poverty, chastity, derision, and freedom from unreal loyalties" to old institutions (TG 79), she is partly reinstating the conditions that have subordinated women in history. In her vision of the harsh fatalities of patriarchy, of fascism, war, and all systems of oppression, a new assertion of feminine otherness appears to be the only mitigation: not a practical measure, not indeed the quickest route to the success (in society's current terms) of the greatest number of women, but a subversion of the whole existing order. Like Eliot, Woolf charged that a peculiar feminine potential till now had been stunted, but no good would come of promoting it in the image of masculine power.

In the spirit of many Victorian reformers, then, Eliot and Woolf retain an ideal of feminine "suffering and sensibility" as a moral advantage ("GE" [1919] 159), in the name not of a clearer separation of the spheres but of a nearer approach to sexual harmony. If femininity is an art which paradoxically is nature, it artfully mends nature by asserting women's influence on culture. Through education, Eliot and Woolf hope, women may fully develop beyond the past when they were seen as outside and opposed to culture. Yet Eliot's and Woolf's visions of sexual harmony echo the Platonic myth of the sexual spheres, a myth underwriting the patriarchal tradition. Eliot proposed (anticipating Woolf's metaphor for personality, the rainbow): "Let the whole field of reality be laid open to woman as well as to man, and then 
... we shall have that marriage of minds which alone can blend all the hues of thought and feeling in one lovely rainbow of promise for the harvest of happiness" ("Woman in France" 81). In A Room of One's Own, Woolf imagines a similar "marriage of minds": "When I saw the couple get into the taxi-cab the mind felt as if, after being divided, it had come together again in a natural fusion. . . . One has a profound, if irrational, instinct in favour of the theory that the union of man and woman makes for the greatest satisfaction, the most complete happiness" (RO 101-2). The dream of gender without oppression still attracts these women of letters as they try to awaken from the nightmare of historical subjection.

Woolf's desire to preserve feminine bloom is more conscious of its own perversity, its conflict with her open desire to promote women's free development. Her confession of an instinctive heterosexism is explained, tellingly, by her having witnessed a tryst between "people in the street" whom she looks "down on," as though the common life around her were another state of nature. In the same passage she describes the alienation when, instead of thinking "back through [her] fathers" she "thinks back through her mothers": when, "in walking down Whitehall, . . . from being the natural inheritor of that civilisation, she becomes . . . outside of it" (101). The position of outsider is, she acknowledges, uncomfortable and difficult to sustain. Hence the relapse into a "state of mind ... without effort," in which one can believe in the reconcilability of sexual difference in its customary costumery: "a girl in patent leather boots, and . . . a young man in a maroon overcoat" (100-101).

Such a vision suggests that Woolf's most effortless outlook on sexuality was the essentialist one she first learned in a Victorian milieu (Gordon 5). Yet Woolf unlike Eliot cannot feel at home in Whitehall for long; she finds no comfort in affirming women's "worse share," except to justify her preference for them. "I like their unconventionality. I like their subtlety. I like their anonymity" (RO 115). The terms in which she expresses this preference suggest that she still clings to the nineteenthcentury ideology of "woman's sphere" while proclaiming women's moral superiority even more explicitly than Eliot would do.

\section{The Context of Social Movements: Ladies and Heroines as Reformers}

We are now in a position to take a closer look at these authors' complex affiliations with contemporary women's causes. I have already touched on two reasons for the authors' distrust of conventional 
politics. The first is the ideology of influence, which exalts qualities that have been shaped by oppression and perhaps depend on it for their existence. The second reason is closely related to the first: a profound distrust of public forms of power, both that of male leaders and that of the common people. Legislated reform cannot respond with novelistic subtlety to the feminine "art" of "nature," or to the complexities of emotions and consciousness. Ordinary people, similarly, tend not only to be poor readers but also to threaten the sensibility (and at times the security) of ladies, no matter how readily ladies acknowledge common cause with them. The refined private insight of cultivated women, strangely enough, is the force with which Eliot and Woolf propose to combat the evils of things as they are: the oppression of common people as well as of all women. At the same time, as women these authors could expect their critics to associate them with the threatening masses and with low art, no matter how ladylike, rarefied, or impersonal their manners. Neither Eliot nor Woolf could be said to have languished amid the mass readership; indeed, they have been reproached for their supposedly unquestioning identification with elitist values, whether those of the liberal intellectual or the upper-class "social parasite" (Cottom 3-31; Leavis 386). Yet both were persistently seized with anxiety about their right to speak, and retained a sense of themselves as outsiders, albeit cultural aristocrats (Hertz 79-80; VW Diary 2: 168, 321).

Defining themselves as outsiders within an elite, as ungendered beings speaking for a feminine common life, Eliot and Woolf necessarily betray inconsistent political affiliations. Indeed, their known relations to contemporary political movements reflect the politics of their own vocations as women of letters. They each lent assent to their associates' efforts to win for women unrestricted education, more just marriage practices, and equitable opportunities to earn a livelihood and control property-all matters that had direct bearing on the career of a woman writer (David 204-6). The sibylline woman writer, like the early women's movements as a whole, must stand aloof from the usual politics of men and the subjection of ordinary women and common people. In so doing, the woman of letters gathered influence to promote sexual and social harmony-or she justified the selfishness of aspiring to greatness as writer or reformer. A closer look at the interconnection of these women of letters and contemporary reform movements should help define both factors: what was the role of the great woman as writer or reformer, and how did contemporaries formulate the "woman question"?

It seems likely that Eliot's cautious approach to the women's move- 
ment was conditioned by her own position. She did sign Barbara Leigh Smith's petition for the Married Women's Property Bill in 1856 (Herstein 84), but having "eloped" with Lewes in 1854 she would of course have been excluded from the benefits of that reform. She must have felt all the more reluctance, because of her anomalous status, to take part in the political action on women's behalf that increased over the following decade. There was already a precedent for discrediting feminism by citing the extramarital liaisons of Mary Wollstonecraft. It seems likely that Eliot might have associated more with the "ladies of Langham Place," or contributed to The English Woman's Journal, founded by Barbara Leigh Smith and Bessie Parkes in 1857, if her social position had not been so equivocal, and if indeed she had not been preoccupied with gaining the authority of a male novelist. ${ }^{6} \mathrm{Her}$ apolitical, "objective" stance is not a coincidence of temperament, but rather the position that enabled her to aspire to "greatness."

Eliot consistently writes as the "natural historian" of culture rather than the reformer of particular laws. She expressed uncertainty about the value of the vote for women (Zimmerman, "Felix Holt," 432-37); in Felix Holt, the Radical and "Address to Working Men, by Felix Holt," for example, she diverts the issues of the recent Reform Bill of 1867, with the concurrent debate about women's rights, to the context of the first Reform Bill in 1832, arguing that working men (and presumably women even more so) are unfit for the franchise in their current state of ignorance. That Eliot did not confine politics to such party matters is demonstrated in her portraits of Harold Transome and Mr. Brooke, gentlemen "radicals" (and misogynists) for differently muddied "personal" reasons, and in her implication of Mrs. Transome and Esther, Dorothea and Rosamond, in public political events. But the great writer strives to appear unimplicated; her art must not serve politics, though she elaborates a definition of politics in her art that evidently implicates everyone.

Woolf was similarly restrained in her contribution to "the cause," fearing the censure of her own work as polemical. Whereas Eliot had cautioned against abruptly legislating change, Woolf asserted that new legal rights had not altered the "cause" — shared by women and men-against "tyranny," "the same fight that our mothers and grand-

${ }^{6}$ Helsinger, Sheets, and Veeder 2: 147; Feltes 45. Eliot termed "second-rate" the literature in Parkes's Waverley Journal (predecessor to The English Woman's) (Haight 243; GE Letters 2: 379-80; Lacey 218). Eliot wrote to Barbara Leigh Smith (later Bodichon) that essays revealing hardships of poor women "will make the Journal a true organ, with a function"; but she deplored the bad reviewer: "I wish Bessie felt more keenly about the immorality of such slack writing" (GE Letters 3: 153, 225-26). See Uglow's lucid account, "George Eliot and the Woman Question in the 1850s," 65-81. 
mothers fought" (TG 102), a matriarchal lineage that included Emily Davies and Barbara Leigh Smith Bodichon, as well as another associate of Eliot's, the physician Elizabeth Garrett Anderson (TG 183n.38, 186n.44). Woolf's "cause," then, is given genealogical respectability, bound closely to the maternal past, though it might seem eager in other ways to break with it." "Revisionist rather than revolutionary" (Rosenman, Invisible Presence, 46), she declares, in E. M. Forster's words, that "women must not condone this tragic male-made mess." Her feminism is indeed "old-fashioned" as Forster says, not as he claims because it is obsolete suffragism but because it takes the revenge of opting out, at least as old as Lysistrata (Forster 33; TG 147n.10). In comparison, Eliot shows less solidarity with the history of women's resistance to oppression and more respect for the public channels of reform: there is no real opting out in Eliot's deterministic world, neither for men who wish to put women and domestic life behind them nor for women ignorant of the "great" movements of politics and culture.

Like Eliot's, Woolf's public position on the women's movement of her day was equivocal, though more active. She took part in some of the suffrage work that Mary Datchet undertakes in Night and Day. From January 1910 she addressed envelopes for the Adult Suffrage movement, at the suggestion of Margaret Llewelyn Davies (Bell 1: 161), who was the original of Mary Datchet and of Eleanor Pargiter in The Years (Marcus, Languages, 26-27), as well as being the niece of Eliot's friend Emily Davies. Woolf worked closely with the younger Davies, and in June 1913 she attended a meeting of the Women's Cooperative Guild (an outgrowth of the nineteenth-century socialist, trade-unionist, and women's-rights movements), yet in her introduction to Davies's collection of the testimony from this meeting, Life as We Have Known It, she expressed her sense of remoteness from working women's experience ("Introductory Letter" xix; "Memories of a Working Women's Guild," CE 4: 134-48).

In Woolf's day it was far less possible than in Eliot's to restrict the women's movement to middle- and upper middle-class reform, and the newly democratic perspective made Woolf uneasy. She herself, like Eliot, would have had no desire to join riots and hunger strikes to gain the vote, thereby forfeiting educated women's difference both from men and from the working classes who likewise fought for the franchise. Safe as a small-scale heiress, Woolf's narrator in A Room of

\footnotetext{
${ }^{7}$ Woolf's mother signed Mrs. Humphry Ward's anti-feminist petition of 1889 . Woolf, "The Compromise," 171; Marcus, Introduction, xix; Bauer and Ritt 260-62.
} 
One's Own can afford to view financial independence as a greater benefit for women than the vote (37); basic economic needs press on women of all classes, but only an educated elite can regard the preconditions of writing as the most elemental rights. Specialized as her concern for the evolution of educated women at times appears, Woolf had broader motives as well for emphasizing intellectual freedom over electoral power. She believed that all women were qualified to join in a collective resistance to forces that oppress all human beings. She withheld her endorsement from the term "feminism," calling it "corrupt" and obsolete (TG 101), largely because it seemed to clamor for equality at the cost of women's "difference," while obscuring the more fundamental cause against "the tyranny of the patriarchal state" (TG 101-3). The vote, if it wedded women to war and all the injustices of patriarchal power, would be an instrument of such harmful indifference. ${ }^{8}$

The women's movement with which Eliot and Woolf were allied derived primarily from liberal individualism, though it also advocated an impersonal altruism. Thus the early "cause" could be read as a heroic narrative of a few ladies who broke out of passive anonymity into the activity of history. In this light, historical women and heroines in novels by Eliot and Woolf may appear to strive for human progress on the same plane, though the purely fictional figures accomplish less (in practical terms) than their counterparts in life. The kinship between some actual lady reformers and these authors' female characters suggests that there were ideological advantages to conceiving women's social action as tending to quixotic idealism (though women's practicality was prized in the home). Generous failure on pure-minded principles somehow earns greatness for reformers and heroines alike.

According to Lytton Strachey's sister-in-law, Ray Strachey (and Woolf adopts this view in Three Guineas), the first movements toward feminism in Britain grew out of the philanthropies organized by ladies whose activity outside the home had traditionally been limited to charity among the poor of their parish; as Strachey puts it, "The feminist movement began through the awakening of individual women to their own uselessness" (13, 44; Bauer and Ritt 80-81). This derivation is true enough for the activists whom Eliot and Woolf

\footnotetext{
${ }^{8}$ Woolf notes that women won the vote because they helped fight the Great War (TG 148n.12), and it was members of the Women's Social and Political Union who handed out white feathers to goad men to enlist (TG 182n.35; Rowbotham 116). Rhetorically, Three Guineas tries to elide difference because fascism is dividing "sexes" and "races": "The daughters and sons of educated men are fighting side by side" (TG 102-3).
} 
personally knew, but it ignores the widespread organization of working-class socialist women's groups alongside the Owenites and Chartists (Strachey does briefly mention these groups: 30-32; Killham; Rowbotham 42; MacKinnon 230-31). Eliot's works epitomize the complex loyalties of the early lady reformers, women who retained their upperclass superiority to the objects of their charity, the poor and the sick, and seldom questioned their allegiance to educated men.

One of Eliot's friends, Bessie Rayner Parkes, advocated the ladylike vocation of systematic charity in terms that read like a rough draft of the Prelude and Finale of Middlemarch:

Among the comparitively [sic] affluent ranks women lament a monotony of existence resulting from the narrow sphere of action assigned them. This becomes the source of an indescribable ennui by which they reproach society, and almost Providence. . . . It is the prerogative only of a few rare natures to find sufficient incitement to exertion. ... Numberless temptations beset this life-torpor. . . . [I]t is to the finest capacities that inactivity proves most detrimental. In such cases there is a consciousness of aspiration for which no available medium of realisation appears. ...

It is in the power of women to become invincible agents in the work of charity. The very attributes of feminine nature are of essential value in such a cause. Funds, programmes, and committees . . . can only partially effect the good which results from . . . charity. Kindly and sympathetic contact, the expression of benevolence ardent and sincere, is needful and irresistible. . . ([1859]; quoted in Bauer and Ritt 83)

Here, the ardor of a lady like Dorothea, her capacity to feel for others, is offered as both her greatest danger (the temptation of discontent) and her saving grace.

The institutionalization of charity coincided with the rise of movements for women's emancipation, as though the deflection of altruism into public channels, answering the personal question "What can I do?," rendered that question at once more pertinent to the nation as a whole. Rosamond Vincy's passive-aggressive "What can $I$ do?" is not, it turns out, antithetical to Dorothea's and the lady reformers' desire to do whatever needs to be done (Lydgate himself compares the two ladies' responses to hardship, recalling Dorothea's unselfish appeal to him on behalf of her husband, "think what I can do" [43234]). In a later context, both the idle and the helpless appeals turn into a healthier demand: let me do whatever I am best at-for the 
betterment of all-and change the laws that prevent me. To the reader in 1871-72, after successive attempts to change the divorce, property, and suffrage laws as well as educational practices, Dorothea must have seemed decidedly a throwback to the first, more hampered lady reformers, as Eliot well knew (this is an aspect of her historical reading of the 1830s). ${ }^{9}$

That Woolf too should have lingered over madonna-like figures of influence such as Mrs. Ramsay suggests their lasting appeal, not simply as historical curiosities extinct like the "Dodo" (Celia's nickname for Dorothea). Mrs. Ramsay, having found what she can do, has an instinct to visit

this widow, or that struggling wife in person with a bag on her arm, and a note-book and pencil with which she wrote down in columns ... wages and spendings, employment and unemployment, in the hope that thus she would cease to be a private woman whose charity was half a sop to her own indignation, half a relief to her own curiosity, and become ... an investigator, elucidating the social problem. (TL 17-18)

In this way, ladies of "the finest capacities" were encouraged to find an activity that would not openly compete with men's administration or violate class structures but that would assume responsibility for "the social problem." Dorothea and Mrs. Ramsay conceive the problem economically, and never lose sight of their difference from the poor and uneducated whom they care for. But their authors clearly include gender with economics and class as a factor in "the gentlewoman's oppressive liberty" (M 202). As a lady, Dorothea can only solve social problems that directly pertain to men in her own circle: the housing on Sir James's estate, Lydgate's and Farebrother's moral and economic standings. Similarly, Mrs. Ramsay busies herself unobtrusively with poor widows and wives, matchmaking, and the well-being of her

${ }^{9}$ Dorothea Beale was a well-known ladylike reformer who educated girls "so that they may best perform [their] subordinate part" (R. Strachey 135), as she assured the Social Science Congress in 1865. Nina Auerbach notes the popular fear of even such conservative reformers, reflected in the ditty "How different from us,/ Miss Beale and Miss Buss!" (Woman, 119). Beale (1831-1906) directed Cheltenham Ladies' College and founded St. Hilda's College, Oxford, for rescue work: the reform of prostitutes. She appears in Leslie Stephen's Dictionary of National Biography. Frances Mary Buss (1827-1894) founded the North London Collegiate School for girls. Both favored women's suffrage, but Beale was most concerned with "duties rather than rights" (Banks). Dorothea Beale suggests to me one prototype for Eliot's Dorothea Brooke, but the real woman was foundress of something. 
household, never venturing to attack the order that subordinates women and the poor while separating women of different classes. Both Dorothea and Mrs. Ramsay remain private women though others around them testify to their widespread influence.

The Victorian hope that more enlightened, organized charity would reconcile both women and the poor to their lots by moderately improving them is dramatically represented in the portrayal of Romola, the Eliot heroine who most distinctly represents the political role of Victorian ladies. Romola has at least two originals, distinguished Victorian women who happened to be cousins, Barbara Bodichon and Florence Nightingale, both of whom came of English "intellectual aristocracy" as the Stephens did (Annan 1-7). Barbara Bodichon became perhaps Eliot's closest friend; among other causes, she founded an innovative school for the poor and organized committees for the Married Women's Property Bill in 1855 and for women's suffrage in 1866, as well as promoting women's higher education. Romola also figures as Eliot's "Lady with the Lamp"; she learns to minister to the ailing masses like Bodichon and like the more famous Florence Nightingale. The latter eminent Victorian had "the highest lot ever fulfilled by woman, except women Sovereigns," according to Harriet Martineau; she achieved "an opening for her sex into the region of serious business" (196; Jameson, Sisters, 112-14).

Far from a feminist, Nightingale nevertheless epitomized the Victorian Public Lady. "She was no declaimer, but a housewifely woman" and thoroughly "lady-like," Martineau assures us (202)- herself severe on unladylike feminists such as Wollstonecraft (81). Nightingale's one loud protest against the idleness of ladies, Cassandra, now wellknown, remained unpublished at the time. To judge by Eliot's novels, she would have advised against publication; her own heroines emulate the quiet good deeds of Nightingale nurses without assuming the public recognition and power of the prototype. Ministers of state consulted Nightingale, whereas Romola cannot prevent her uncle's politically engineered execution. Dorothea dreams of founding a cooperative agricultural community, but she ends by helping Ladislaw behind the political scenes. Fittingly, Nightingale objected to Eliot's portrait of Dorothea as a poor substitute for the successful housing reformer Octavia Hill. ${ }^{10}$ Eliot, it seems, was rather more discouraging than some of her contemporaries as to the range of achievement for women (or at least heroines) who bore their charitable vocation outside

\footnotetext{
${ }^{10}$ Showalter, "Greening," 305-6. Woolf discusses Hill in Three Guineas (165n.35). Eliot donated $£_{200}$ to a fund supporting Hill's projects (GE Letters 6: 31 ). Hill was a kind of daughter-in-law to Eliot, as sister-in-law to Lewes's son Charles.
} 
the home. Yet her most honored heroines, Romola and Dorothea, are close cousins of the early lady reformers.

Woolf, in contrast, was more likely to exalt than to disparage these ladies' achievements. She loyally calls for the preservation of the charm of the nineteenth-century lady reformers, the "unpaid-for education" that made them "civilized human beings" eschewing "egotism" and love of "fame." She cites Florence Nightingale, Anne Clough, Mary Kingsley (TG 76-79, 82), Josephine Butler, Sophia JexBlake, and Barbara Bodichon as well as Elizabeth Barrett, Charlotte Brontë, and Mrs. Gaskell (TG 130-37)-all contemporaries, acquaintances, or close associates of Eliot-and she elaborates on the obstacles to women's achievement that these reformers courageously overcame. Woolf nevertheless seems to savor their role as rebellious daughters, as new Antigones, which would be lost if they had not in some sense failed like the literary heroines (TG 81, 169n.39). Like Eliot exalting an obscure Romola or Dorothea, Woolf honors the civilized selflessness of Victorian ladies as the pearl of patriarchal oppression (TG 78-79). ${ }^{11}$ Women's influence was offered as a compensation for their ostensible powerlessness; influence could, to a degree, tangibly improve conditions for the less fortunate. Like Mrs. Ramsay as well as Julia Stephen, Eleanor Pargiter in The Years visits the poor and even helps construct more and better housing for them, as though fulfilling the promise of Dorothea as well as of Octavia Hill.

The model for both the public reformers and the fictional heroines derives from an ideology of influence that itself was influenced by a shift in the perspective of social thought. For middle-class women at mid-century, the most immediate crisis was the lack of education and employment for "redundant," that is unmarried, middle-class women (Poovey 1-15). The discovery of this redundancy through the 1851 census was itself symptomatic of a new tendency to regard society as a subject of study like any aspect of natural science. Just as Eliot herself worked closely with Herbert Spencer and her "husband," a selftrained scientist, many women reformers were allied with the rising social sciences, which, while promising to demystify the bases of the social order, could also serve to justify individual suffering as part of a progressive plan. At the same time, the methods of social science helped organize charity on a scale to influence lawmakers, by docu-

\footnotetext{
${ }^{11}$ I discuss the use of the Antigone prototype in Chapter 4, but here I note that Woolf speaks for Eliot as well when she claims that "ridicule, obscurity and censure are preferable, for psychological reasons, to fame and praise," and that women especially must avoid prostituting themselves; art must be pursued "for the sake of the art" (TG 80).
} 
menting the abuse of women and children in factory labor, for instance. The National Association for the Promotion of Social Science, founded in 1857, was one of the first learned societies to admit women and to allow them to read papers at meetings (Bauer and Ritt 8o). The new social science offered women "something to do" as investigators of the social problem from the vantage of educated circles. Many readers of Eliot have supposed that she defined her vocation in terms of a sociological "something to do," but few have traced the particular utility of Comtean positivism, a source of the new sociology, for her vocation as a lady reformer (Vogeler 407). Indeed, scholars have focused on Comte's positivism to the neglect of his adaptation of current ideas of woman's "Mission," obscuring the gender politics that supported sociology, like other empiricist science, from the beginning (Harding 85-92). Envisioning "woman as the moral providence of our species," Comte promotes a new "Positive Religion" in which women are the saints, duty-bound to remain chaste, abstain from politics or work outside the home, and espouse motherhood or perpetual widowhood as their highest goal. ${ }^{12}$

Both Eliot and Woolf could interpret the destructive inconsistencies of such an ideal, yet they remained attracted to it. In spite of her skepticism about Comte's philosophy, Eliot tended to exalt as he did women's superior capacity for submission to a communal good (Newton 135-37), and her heroines often stand in for saints. For Woolf, chastity and behind-the-scenes influence on social cohesion remain ideals. Like Sarah Lewis in Woman's Mission, the author of Mrs. Dalloway might have argued that influence is more effective than power as it commands "unconscious acquiescence" (Lewis 13); Clarissa, who sleeps alone in her narrow bed, serves goddess-like to unite the many souls at her party. The "intellectual chastity" Woolf espouses for educated men's daughters in Three Guineas might be a polemical caption

\footnotetext{
${ }^{12}$ Comte aims "to direct the thoughts of women and working men to the question of a thorough renovation of the social order" (emphasis added; The Catechism of Positive Religion, 14, 20-38). This work was published in English by Eliot's former intimate, John Chapman, early in her career as a novelist (1858). Earlier, Harriet Martineau had translated and condensed Comte's Positive Philosophy (Comte and Positivism 69-306). The Positivist Calendar assigns a great name to every month and day of the year, and among the great men includes "Heloise," "Joan of Arc," and "St. Theresa," as well as "Sappho," "Mme. de Staël," and "Miss Edgeworth," among twenty or so other women. An "Additional Day in Leap Years" would be honored as the "Festival of HOLY WOMEN" (Comte and Positivism 472-73). Martha Vogeler points out how Middlemarch violated Comtean doctrine: the wife of a man of science destroys him rather than "inspiring him by superior moral virtue," while the widow of a scholar remarries (417). Comte himself defies the establishment of "pure science" in which woman figures as the passive body of Nature penetrated by man (Harding 118; Showalter, Sexual Anarchy, 128-33).
} 
for the Comtean tableau that Romola, perpetual widow, arranges at the end of Eliot's novel (Myers, Teaching, 96-97; Levine, "Hypothesis," 3; Marcus, Languages, 117).

\section{Education, Class, and Hothouse Cultivation}

Most of the Victorian reformers sought to establish a less treacherous basis than Comte's for the ideology of influence, while they disparaged the association of all women with working-class outsiders (except through sympathy). Rather, they endeavored to gain for women of the middle and upper classes the same access to cultural privilege as their brothers enjoyed. As a reform movement, the cause of higher education for women was relatively unthreatening, since there was little danger at first of including untold masses in the scheme (Altick 143; Brantlinger 238-39, 246-47). Eliot endorsed women's educational reform, including the efforts of her friends Barbara Bodichon and Emily Davies to raise support for Girton College; she contributed $£_{50}$ "from the author of Romola" —in itself a statement (given Romola's broken ambitions) that the vocation of charity, not learning, was most fitting for women (Redinger 453). Ironically, under the ladylike auspices of Girton, Eliot was not welcome (as a Victorian Romola would have been) to visit the college openly, and had to enter by the back drive (Bradbrook 14-15). As Ray Strachey observes, her support of the college was "of no use in reassuring the public about [its] absolute respectability" (147). Such was Eliot's authority, however, that she was later consulted as to the propriety of the women's acting in college theatricals in men's costumes; in spite of her own use of a male pseudonym, Eliot concurred with other authorities that "Hamlet must be played in a skirt" (Woolf, "Two Women," CE 4: 64; compare Lucy Snowe's compromise as the male lead in a girls' school theatrical in Villette). Such also was the lasting importance of Eliot as a leading example of female achievement that Margaret Llewelyn Davies donated a sketch of George Eliot to Girton College in 1923 (Haight 339).

Like Eliot and her associates, Woolf focused her feminism on education. Sandra M. Gilbert offers a persuasive reading of $A$ Room of One's Own and Orlando as manifestos for a liberal education on women's terms ("The Battle of the Books"); in Three Guineas, moreover, Woolf invents her own women's college (Marcus, Languages, 116). A Room of One's Own, originally delivered as lectures at Newnham and Girton, pictures a visit to "Fernham," much as though Woolf herself were calling on her cousin Katherine Stephen, principal of Newnham (Mar- 
cus, Languages, 82). Woolf is, of course, welcome to enter by the front door. In Woolf's day, lady reformers appear to have been less anxious to preserve the propriety of gender than the propriety of class, as the latter hierarchy no longer could be invoked as natural. Educational reform had taken a much more democratic cast, and the spectacle of the suffragette movement had dramatized the distinct differences between the interests of all women and those of all men, regardless of shared interests between sexes within each class. Thus Woolf has her own version of the bloom that must be preserved, not of chastity but of cultivated privilege and impractical beauty.

In "Two Women," a review of Lady Stephen's book, Emily Davies and Girton College, Woolf obliquely addresses the interrelated issues of women's education and of class. In Woolf's view, Davies and other exceptional women such as Barbara Bodichon overcame the middleclass woman's "negative education" in how to be useless. Woolf contrasts their ambitious achievements with the sequestered, placid life of Lady Augusta Stanley. The conclusion is uncertain: "There is something in Lady Augusta's power to magnify the common and illumine the dull which seems to imply a very arduous education behind it. Nevertheless, . . . one cannot doubt that Miss Davies got more interest, more pleasure, and more use out of one month of her life than Lady Augusta out of a whole year of hers" (CE 4: 66). The lady herself " 'wished to be a fellow of a college,' " and did in fact join Davies's cause to create a women's college. Woolf imagines that this cause brought about a "union of the middle-class woman and the court lady" - like her own wishful union with an Orlando/Sackville-Westbearing "some astonishing phoenix of the future who shall combine the new efficiency with the old amenity, the courage . . . [and the] charm" (CE 4: 66). Woolf would perhaps conceive herself as that future being, combining all Eliot's learned yet charmless force with an aristocratic "power to magnify the common."

Like Martineau assuring us that Nightingale was "lady-like," Woolf prefers her female predecessors to be civilized ladies; it is even preferable that they should have been defeated in their goals than that they should stridently have demanded too much. In her 1919 essay on Eliot, Woolf seems to betray her own resentment that Eliot was not really a lady, raising the class issue that dominates the question of women's access to privileged culture. "We know . . . that the culture, the philosophy, the fame, and the influence were all built upon a very humble foundation-she was the grand-daughter of a carpenter" ("GE" [1919] 152; see also the opening sentence of "GE" [1921]). For Woolf, the great-granddaughter of a Master in Chancery, the privilege 
of class meant certain literary privileges, the power to charm critics of that class; Eliot, supposedly, was "out of her element" "in middle-class drawingrooms" ("GE" [1919] 158). ${ }^{13}$ But Eliot had done everything she could to extricate herself from the provincial society of Dodsons and Tullivers that so strictly limits women's education and development. The novels from Romola on might seem repeated demonstrations that the author was perfectly at home in middle-class drawing rooms, and that her advocacy of women had no tinge of vulgar demands for personal rights.

Along with concerns about class and ladylike respectability, the question of the education and cultural achievement of women seems by a kind of reflex to raise images of the garden or conservatory. If women have the art which does mend nature, which is nature, are women in themselves a cultivated form of nature? Rather than resorting to the ancient analogy between women and animals, those who wished to maintain the innate lack of passion and appetite in women readily imagined them as flowers or fruits. Curiously, advocates of the liberation of the sex often called up the age-old imagery of the enclosed garden in answer to those who would plant women there.

In one of the most eloquent arguments against the "intention of nature" fallacy (and one of many disturbing liberal analogies between slavery and womanhood), John Stuart Mill claims that slaves have at least been allowed some "liberty of development" as to their character,

but in the case of women, a hot-house and stove cultivation has always been carried on of some of the capabilities of their nature. . . . Certain products of the general vital force sprout luxuriantly . . . in this heated atmosphere and under this active nurture ... , while other shoots . . . left outside in the wintry air ... have a stunted growth, and some are burnt off with fire ... Men . . . indolently believe that the tree grows of itself in the way they have made it grow, and that it would die if one half of it were not kept in a vapour bath and the other half in the snow. (Subjection 39)

Mill is not deliberately longing for a natural, organic womanhood, since his entire treatise insists that development be understood as the result of environmental influence, but he can't help arousing our sentiment for the vulnerable tree and how it might have grown with-

\footnotetext{
${ }^{13}$ The relation between Woolf and Eliot might be compared to the first confrontation between Katharine Hilbery and Ralph Denham, two representatives of the middle class, one who must "live up to . . ancestors" and the other who must live down his "dull," bill-paying family (ND 17-18).
} 
out man's interference. The desire to protect womanhood from the distortions of civilization can be seen in writings on both sides of the question of women's education and rights.

Both Eliot and Woolf, like their contemporaries, seem drawn to what for convenience I will call horticultural imagery. We might consider these images as a literalization of the metaphor of culture (Jacobus, Reading Woman, 72-73). In the conservatory, how can one tell the intention of nature from the nurture that has artfully mended it? Eliot, picking up on the current aspersions on the cultivation of girls, plays out these images in the portrait of Gwendolen Harleth, herself serpentine and meaning to lead. Gwendolen scoffs at "reforming women," yet is "inwardly rebellious against the restraints of family conditions" (DD 83); she tells Grandcourt that feminine bloom, confined to the domestic hothouse, often grows "poisonous" from boredom (171). Eliot attributes the serpentine corruption of young women like Rosamond or Gwendolen to a cultural law of supply and demand: "Men's taste is woman's test" (DD 132). Girls are artificially cultivated to be sold in the market for idle ladies, and the taste might well prove poisonous. In the eyes of many, however, girls like Gwendolen had been spoiled by promiscuous exposure to a man's world; too much rather than too little education was to blame. As Meredith's Egoist, Sir Willoughby Patterne, exclaims to himself, "Without their purity what are [women]!- what are fruiterer's plums?-unsaleable. O for the bloom on them!" (114). Even some educators like Anne Jemima Clough were anxious to segregate female education to preserve the bloom. ${ }^{14}$

As a connoisseur of bloom, Ruskin could insist that woman is not to be the "shadow" or "slave" of man but that she should enjoy chivalrous influence over him as "Queen" of her "Garden"; like Mill, he objects to the artificial cultivation of girls.

You may chisel a boy into shape. . . . But you cannot hammer a girl into anything. She grows as a flower does,--she will wither without sun; she will decay in her sheath, as the narcissus does, if you do not give her air enough; she may fall, and defile her head in dust, if you leave her without help . . . ; but . . . she must take her own fair form and way. . . . Let her loose in the library, I say, as you do a fawn in

${ }^{14}$ B. A. Clough, Memoir of Anne Jemima Clough (1897), 195, in Hollis 6; R. Strachey 143. Martineau asserted that girls could learn everything their brothers did with greater facility, freeing a third of their day for studying the household arts $(118,120)$. Woolf notes that Charlotte Yonge blamed women for their own "inferiority": "She reminded her sex of a painful incident with a snake in a garden" ("Two Women," CE 4: 62). 
a field. It knows the bad weeds twenty times better than you; and the good ones too. $(50,66-67)$

This apparent permissiveness, it becomes clear, is only due to Ruskin's assumed confidence that a woman will grow into a willing tender of other flowers, and that she will acquiesce in her domesticity ("home is always around her ... home is yet wherever she is" [6o]). The emphasis is still on nurture, on the civilized containment in dwelling or garden of what might otherwise simply be nature.

Most partisans of women's genuinely unlimited development were not so confident that the garden analogy was benign. Mary Wollstonecraft, back in 1792, blamed "a false system of education" for women's "barren blooming," "like the flowers which are planted in too rich a soil" (85). In the 1850 s and later, some feminist reformers suspected educational hothouses might only be a new cover for patriarchal venom. Emily Davies called the offer of separate examinations for women a "serpent" (Strachey 143), suggesting the negative side of the garden imagery, with its inevitable Miltonic and biblical associations. Feminists could exonerate Eve in attacking the serpent, perhaps, but they might also deplore the feminine weakness of some of the latterday products of the garden, as Wollstonecraft does. Josephine Butler described women trained for the profession of marriage as "Brazilian creepers . . . which sprawl out their limp tendrils . . . to find something to hang upon" (Introduction, Woman's Work and Woman's Culture [1869], in Hollis 10); the conservatory is a deadly place, apparently, and robust women must grow elsewhere.

Woolf, like her Victorian predecessors in the women's movement, resorts to imagery of exotic, domesticated nature when considering women's education, but she was as likely to defend the protected, "natural," Ruskinian education of the girl at home (indeed, this was the mode of her own education) as she was to criticize the artificiality of such cultivation. In spite of her admiration for Lady Augusta's protected charm, she deplored an excess of femininity: "The power of sympathy, when so highly developed . . . tends to produce a hothouse atmosphere in which domestic details assume prodigious proportions and the mind feeds upon every detail of death and disease with a gluttonous relish. [The volume of Lady Augusta's letters] is all personal, emotional, and detailed as one of the novels which were written so inevitably by women" ("Two Women," CE 4: 65). The poisonous intimacy of the hothouse does not, however, drive Woolf into the "masculine" open air; unlike Emily Davies, she would not have insisted that women's education must be in all things equal to men's. 
In a commentary on Euphrosyne written in 1906, Woolf defends "that respectable custom which allows the daughter to educate herself at home. . . . which preserves her from the omniscience, the early satiety, the melancholy self-satisfaction" of her university-educated brothers (Bell, appendix C, 1: 205). The criticism of masculine smugness is telling, as though the brothers are the ones who grow poisonous on too rich a soil.

Woolf herself contributed to the education of working women by teaching history and composition at Morley College from 1905 to 1907, and we see her depicting her pupils as inarticulate nature, though without the delicate bloom of flowers-perhaps because they are not ladies. Impressed with working women's uncultivated intelligence, she takes the place of the "masculine" cultivator: "It would not be hard to educate them sufficiently to give them a new interest in life; They have tentacles languidly stretching forth from their minds, feeling vaguely for substance, \& easily applied by a guiding hand to something that [they] could really grasp" (Bell, appendix B, 1: 203). In the portrait of Rachel Vinrace, in The Voyage Out, Woolf's imagery is less monstrous, as befits a lady. Rachel's education is Ruskinian, typical of "the majority of well-to-do girls in the last part of the nineteenth century"; she has only a smattering of confused information gleaned from private tutors, but she has been allowed to indulge her talent for music, and she has "abundant time for thinking." Her sense of captivity in an artificial social system is concentrated on the memory of the "sickly horrible" scent of "the little hall at Richmond laden with flowers on the day of her mother's funeral" (VO 33-36), and her doom is met in the jungle. ${ }^{15}$

The association of women with nature, usually the liminal nature of domesticated exotics, is directly bound to images of death and loss, as The Voyage Out suggests. Education indeed threatened the bloom; it would figuratively open the hothouse and let women breathe as human beings, at peril to their existence as ladies. The serpent of man's supremacy or desire to possess the woman already lurks in this already-fallen garden; the plants themselves are raised to be poisonous, tempting others and dying prematurely, as Wollstonecraft says: "The flaunting leaves, after having pleased a fastidious eye, fade, disregarded on the stalk" (85). Even the most enlightened attempts to

\footnotetext{
${ }^{15}$ Clarissa Dalloway recalls Sally Seton "like some bird or air ball that has flown in, attached itself for a moment to a bramble." Walking together on the terrace, "passing a stone urn with flowers in it[,] Sally stopped; picked a flower; kissed her on the lips" (MD 51-52). Isa Oliver is clearly associated with the greenhouse in Between the Acts, while Mrs. Ramsay is preoccupied with repairing the greenhouse roof.
} 
protect women from the early doom of sexuality by cultivating their intellects and their independence seem haunted by danger. That a women's college could itself become a kind of conservatory is suggested by the anecdote about Eliot's covert visit to Girton, as though the strong-minded woman were a more dangerous serpent even than men; the pioneering project had to be especially vigilant against the blight of scandal.

In Woolf's view, Eliot must have been better off exploring the territories of learning on her own than attending a college modeled on men's institutions ("Two Women," CE 4: 66). Conceiving the predicament of cultivated Victorian women in the conventional horticultural terms, Woolf explicitly figures Eliot as a greenhouse captive much like Gwendolen or the other heroines. Reviewing The Letters of George Eliot, edited by R. Brimley Johnson, Woolf wrote of Eliot: "Fate had planted her in such surroundings that it was only by breaking the pot itself that she could escape. . . . To dream of seeing 'the bread fruit tree, the fan-palm, and the papyrus,' and at last actually to see them at Alton Garden were scarcely enough to fill a life" ("GE" [1926]). Earlier, in the centenary essay, Woolf had pictured Eliot both as one who escapes the confines of her upbringing and as an interloper in the garden: "She must reach beyond the sanctuary [of womanhood] and pluck for herself the strange bright fruits of art and knowledge" ("GE" [1919] 160).

Eliot and Woolf were closely associated with the feminist efforts of educated men's daughters in their day, as we have seen, but they found that the Grand Old Woman of English Letters must ambivalently subscribe to the ideology of influence, because a publicly politicized stance on women's issues would preclude the cultural privilege they struggled to gain. In this light we may be less surprised by their loyalty to prescribed differences between the sexes; it is as though they believe that the garden or conservatory must remain inviolate even when the "natural" products of such nurture have grown poisonous with resentment and frustration. They were urgently writing like women who had forgotten they were women-obliterating whatever might distinguish them from any "human" writer-while what they wrote posed over and over the vexed question of womanhood, the dangers and appeals of the ideology of influence. Questioning the constitution of the human, and demonstrating in their works the interpenetration of public and private spheres, they still retained the ideal of feminine selflessness as though it were the quality of mercy to soften the "justice" or injustice of a deterministic, masculinist world. 